\title{
Case Report: Ramipril and microscopic colitis; a necessary tool of cardiologists can rarely be devastating for patients [version
}

\section{1; peer review: 2 approved]}

\author{
Saad Hasan (iD), Haseeb Ur Rahman (D), Stephen Hutchison
}

Cardiology Department, Nevill Hall Hospital, Abergavenny, Monmouthshire, NP7 7EG, UK

V1 First published: 09 Sep 2020, 9:1113

https://doi.org/10.12688/f1000research.25552.1

Latest published: 09 Sep 2020, 9:1113

https://doi.org/10.12688/f1000research.25552.1

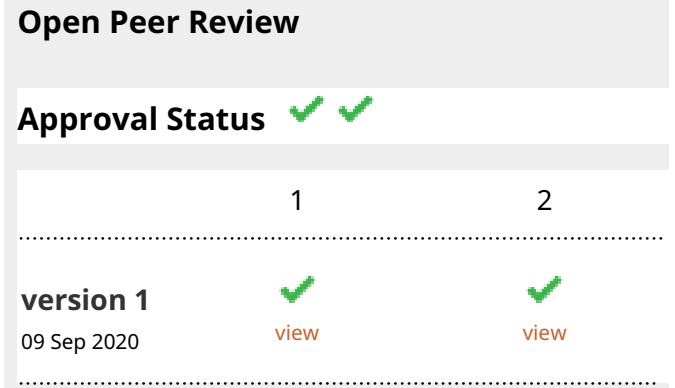

1. Mujeeb Ullah Makki, Royal Worcestershire Acute Hospital NHS Trust, Worcestershire, UK

2. Syed Mujtaba Hasnain Nadir, Health

Education England, North West Deanery, UK Any reports and responses or comments on the article can be found at the end of the article. and nocturnal symptoms during his admission to hospital. The explosive and watery nature of diarrhoea with urgency was so troublesome that it delayed coronary revascularisation and lead him to have significant psychological distress and low mood while nocturnal bowel motions meant he was unable to sleep. He was compliant with his pancreatic enzyme replacement therapy during this period. Infective causes were ruled out by stool microbiology examination and coeliac disease by oesophagogastroscopy and biopsy. It was noticed that he was recently prescribed ramipril that was later stopped as a possible diarrhoea trigger. Diarrhoea started settling immediately and resolved to his baseline within a week. A colonoscopy was performed in the meantime and biopsies demonstrated microscopic colitis (MC). He did not tolerate budesonide well so was stopped. However, a follow-up colonoscopy with biopsy in two months showed resolution of MC.

Keywords

Ramipril, microscopic colitis, diarrhoea, bowel incontinence 
Corresponding author: Saad Hasan (drsaadhasan@gmail.com)

Author roles: Hasan S: Conceptualization, Writing - Original Draft Preparation, Writing - Review \& Editing; Ur Rahman H: Project Administration, Writing - Original Draft Preparation, Writing - Review \& Editing; Hutchison S: Conceptualization, Supervision, Writing Review \& Editing

Competing interests: No competing interests were disclosed.

Grant information: The author(s) declared that no grants were involved in supporting this work.

Copyright: ( 2020 Hasan S et al. This is an open access article distributed under the terms of the Creative Commons Attribution License, which permits unrestricted use, distribution, and reproduction in any medium, provided the original work is properly cited.

How to cite this article: Hasan S, Ur Rahman H and Hutchison S. Case Report: Ramipril and microscopic colitis; a necessary tool of cardiologists can rarely be devastating for patients [version 1; peer review: 2 approved] F1000Research 2020, 9:1113 https://doi.org/10.12688/f1000research.25552.1

First published: 09 Sep 2020, 9:1113 https://doi.org/10.12688/f1000research.25552.1 


\section{Introduction}

Angiotensin converting enzyme inhibitors (ACE-I) are widely used in the treatment of hypertension and heart failure and considered as a safe option. They are usually well tolerated in up to $90 \%$ of patients ${ }^{1}$ while diarrhoea is noticed in up to $8 \%{ }^{2}$. We report a case of severe diarrhoea associated with ramipril use.

\section{Case report}

A 74-year-old man, farmer by profession, admitted from the $\mathrm{A} \& \mathrm{E}$ department where he presented with non-specific upper abdominal pain involving epigastrium and right upper quadrant. He had been drinking excessive alcohol for the previous three days. There was a previous history of alcohol excess, but he had been abstinent for ten years. The patient's past medical history also included triple vessel coronary artery disease, for which he was awaiting revascularisation planned in three weeks time. He also had alcohol-related liver cirrhosis, chronic pancreatitis, diverticular disease, hypothyroidism and asthma. His regular medications included bisoprolol, lansoprazole, clopidogrel, isosorbide mononitrate, levothyroxine, atorvastatin, spironolactone, citalopram, amlodipine, thiamine and pancreatic enzyme replacement. He lived with his wife and was independent with activities of daily living.

On examination, the patient's blood pressure was 79/51 $\mathrm{mmHg}$, pulse $84 / \mathrm{min}$, respiratory rate 17 and he was afebrile. Abdominal and chest examinations were within normal limits. Electrocardiography showed normal sinus rhythm with heart rate of 85 per minute. No ischemic changes were noticed. Computed tomography (CT) scan of abdomen and pelvis did not conclude acute pancreatitis or bowel obstruction but already known diverticular disease.

Blood tests revealed raised high sensitivity troponin of 422 nanogram/litre (ng/L) with subsequent values at 3 hours and 6 hours being $403 \mathrm{ng} / \mathrm{l}$ and $385 \mathrm{ng} / \mathrm{L}$ respectively (normal range $0-34 \mathrm{ng} / \mathrm{L}$ ). Serum amylase was normal. He was treated as non-ST elevation myocardial infarction with standard therapy. Ramipril was also commenced at $2.5 \mathrm{mg}$ once daily dose. He was then planned for inpatient revascularisation.

In about 7 to 10 days of starting ramipril, the patient developed severe exacerbation of his ongoing chronic diarrhoea when he started opening his bowels fifteen to twenty times from about four to five times a day. The bowel motions were watery and explosive in nature with associated severe urgency leading to bowel incontinence episodes, which occurred on a daily basis. As a part of work up of this diarrhoea, stool samples to look for Clostridium difficile toxin, salmonella, shigella, Campylobacter, Escherichia coli 0157, ova, cysts, parasites and Cryptosporidium were sent, which all came back as negative. Faecal elastase could not be tested because of excessively watery stool, as artificially low elastase levels are expected in such samples. Oesophagogastroscopy with duodenal biopsies did not explain the cause of diarrhoea.

During the period in which diarrhoea was being investigated, which had also delayed the planned cardiac intervention, the patient continued to suffer with severe debilitating symptoms. He was unable to get good sleep at night due to the sudden urges to open bowels, which often lead to incontinence. He would have to change his trousers about two to three times on average every night due to this. It also understandably resulted in severe psychological distress and low mood. This was a cause of concern amongst medical team looking after him and a sense of urgent need to get to the bottom of this issue surfaced.

The patient was then planned for repeat CT scan of the abdomen and pelvis after specialist gastroenterology input. It did not show any interval changes in comparison to the previous CT scan performed 4 weeks ago. Comments were made on intra-abdominal vasculature noting heavily calcified abdominal aorta. The origins of the superior mesenteric artery and celiac artery, although calcified, were widely patent.

Drugs were reviewed and lansoprazole withheld to no avail. Afterwards ramipril was stopped approximately a month after it was commenced, which was one of the newly started medications after patient's admission to the hospital, and this immediately lead to some improvement of symptoms. It was followed up by flexible sigmoidoscopy with biopsies taken from distal sigmoid colon, which showed diffuse increase in chronic inflammatory infiltrate. There was also patchy increase in basement membrane thickening and focal epithelial sloughing as features of collagenous colitis. A trial of budesonide was commenced after the biopsy results came back by gastroenterologist at $3 \mathrm{mg}$ three times daily for two weeks with a plan to reduce it to $3 \mathrm{mg}$ twice daily for two weeks and then $3 \mathrm{mg}$ once daily for two weeks and then to stop. Budesonide caused significant abdominal discomfort and nausea, so it was stopped 15 days later, when the patient was seen in the outpatient clinic by gastroenterologist.

The diarrhoea had continued to settle, and bowel motion frequency had gone back to his pre-hospital admission baseline within one to two weeks of stopping ramipril. He underwent successful staged multi-vessel percutaneous coronary intervention and was discharged home after remaining an inpatient for a total of two months.

The patient was followed up as outpatient after two months with colonoscopy and biopsies taken again which came back as negative. Histology showed normal mucosal crypt architecture and no active inflammation which meant that MC had resolved.

\section{Discussion}

ACE-I have been known to cause diarrhoea owing to different aetiologies, including eosinophilic gastroenteritis ${ }^{3}$ and bowel angioedema ${ }^{4}$. MC is less commonly associated with ACE-I ${ }^{5}$.

MC is a known cause of chronic watery diarrhoea, which can also cause faecal incontinence and abdominal pain. On histology, there is increased intraepithelial lymphocytes in lymphocytic colitis with loss of cell architecture and collagen band in sub- epithelium in collagenous colitis ${ }^{6}$. 
Drugs are often implicated in MC. Common ones are proton pump inhibitors, non-steroidal anti-inflammatory drugs, selective serotonin reuptake inhibitors and beta blockers. ACE-Is also increase the risk of $\mathrm{MC}^{7}$.

Usually conservative measures, such as withdrawing the offending drug, can help resolve mild to moderate MC. To reach a conclusion that a drug is responsible, a thorough history should be taken to establish a relationship between starting the drug and development of symptoms ${ }^{6}$. Obviously, clinical context needs to be taken on board and more common causes should be ruled out first.

\section{Conclusion}

Although ACE-Is are less commonly associated with MC, they are extensively used and hence can affect a large number of patients. Cardiologists need to be aware of this potential problem.

\section{Consent}

Written informed consent for the publication of the manuscript and any associated images was obtained from the patient.

\section{Data availability}

All data underlying the results are available as part of the article and no additional source data are required.
1. Amadio P Jr, Amadio PB, Cummings DM: ACE inhibitors. A safe option for hypertension and congestive heart failure. Postgrad Med. 1990; 87(1): 223-6, 231-2, 235-43. Review. PubMed Abstract | Publisher Full Text

2. Mangrella M, Motola G, Russo F, et al.: [Hospital intensive monitoring of adverse reactions of ACE inhibitors]. Minerva Med. 1998; 89(4): 91-7. Italian. PubMed Abstract

3. Barak N, Hart J, Sitrin MD: Enalapril-induced eosinophilic gastroenteritis. J Clin Gastroenterol. 2001; 33(2): 157-8. PubMed Abstract | Publisher Full Tex

4. Gabriel JG, Vedantam V, Kapila A, et al.: Recognizing a Rare Phenomenon of Angiotensin-Converting Enzyme Inhibitors: Visceral Angioedema Presenting with Chronic Diarrhea-A Case Report. Perm J. 2018; 22:
17-030.

PubMed Abstract | Publisher Full Text | Free Full Text

5. Lucendo AJ: Drug Exposure and the Risk of Microscopic Colitis: A Critical Update. Drugs R D. 2017; 17(1): 79-89. Review. PubMed Abstract | Publisher Full Text | Free Full Text

6. Park T, Cave D, Marshall C: Microscopic colitis: A review of etiology, treatment and refractory disease. World J Gastroenterol. 2015; 21(29): 8804-10. Review.

PubMed Abstract | Publisher Full Text | Free Full Text

7. Masclee GM, Coloma PM, Kuipers EJ, et al: Increased risk of microscopic colitis with use of proton pump inhibitors and non-steroidal antiinflammatory drugs. Am J Gastroenterol. 2015; 110(5): 749-59. PubMed Abstract | Publisher Full Text 


\section{Open Peer Review}

\section{Current Peer Review Status:}

\section{Version 1}

Reviewer Report 14 March 2022

https://doi.org/10.5256/f1000research.28199.r125826

(C) 2022 Nadir S. This is an open access peer review report distributed under the terms of the Creative Commons Attribution License, which permits unrestricted use, distribution, and reproduction in any medium, provided the original work is properly cited.

\section{Syed Mujtaba Hasnain Nadir}

Health Education England, North West Deanery, UK

The case is described in adequate detail and common differentials are excluded by relevant investigations. Furthermore, there is a histology proven diagnosis of Microscopic Colitis.

As per standard of care, the patient must have been given Aspirin as a treatment for his NSTEMI. Aspirin is a commoner cause of MC. Please specify in your case report whether Aspirin was continued after revascularization? Furthermore, the patient is on a PPI which is also a common cause of MC, was this discontinued?

Is the background of the case's history and progression described in sufficient detail? Yes

Are enough details provided of any physical examination and diagnostic tests, treatment given and outcomes?

Yes

Is sufficient discussion included of the importance of the findings and their relevance to future understanding of disease processes, diagnosis or treatment? Yes

Is the case presented with sufficient detail to be useful for other practitioners? Yes

Competing Interests: No competing interests were disclosed.

Reviewer Expertise: Gastroenterology

I confirm that I have read this submission and believe that I have an appropriate level of expertise to confirm that it is of an acceptable scientific standard. 
Reviewer Report 14 December 2020

https://doi.org/10.5256/f1000research.28199.r75085

(c) 2020 Makki M. This is an open access peer review report distributed under the terms of the Creative Commons Attribution License, which permits unrestricted use, distribution, and reproduction in any medium, provided the original work is properly cited. The author(s) is/are employees of the US Government and therefore domestic copyright protection in USA does not apply to this work. The work may be protected under the copyright laws of other jurisdictions when used in those jurisdictions.

\section{Mujeeb Ullah Makki}

Royal Worcestershire Acute Hospital NHS Trust, Worcestershire, UK

In my opinion, content in this case report is well structured and organized. Appropriate history, examination and investigations were ordered. They have excluded other causes which could contribute to diarrhea in this patient. Author has also provided histological evidence of MC which improved after stopping ACEI.

There are few points/editions which I will recommend for this case report. Case report is acceptable for indexing with these minor editions/changes:

Computed tomography (CT) scan of abdomen and pelvis did not conclude acute pancreatitis or bowel obstruction but already known diverticular disease.(please rephrase sentence).

Any explanation for complete resolution of chronic diarrhea which was complicated by chronic pancreatitis? Did ACEI settled chronic pancreatitis and lead to complete resolution of chronic diarrhea or patient was still having few episodes of loose stool but had histologically improved MC?

The patient was then planned for repeat CT scan of the abdomen and pelvis after specialist gastroenterology input. It did not show any interval changes in comparison to the previous CT scan performed 4 weeks ago(please mention what was CT report 4 weeks ago? Any comments on pancreas?)

Please recheck references and write according to journal policy.

Once author has done these changes and discussed these points in his report, it can be accepted for indexing.

Is the background of the case's history and progression described in sufficient detail? Yes

Are enough details provided of any physical examination and diagnostic tests, treatment given and outcomes?

Yes

Is sufficient discussion included of the importance of the findings and their relevance to future understanding of disease processes, diagnosis or treatment? 
Yes

Is the case presented with sufficient detail to be useful for other practitioners?

Yes

Competing Interests: No competing interests were disclosed.

Reviewer Expertise: Gastroenterology

I confirm that I have read this submission and believe that I have an appropriate level of expertise to confirm that it is of an acceptable scientific standard.

The benefits of publishing with F1000Research:

- Your article is published within days, with no editorial bias

- You can publish traditional articles, null/negative results, case reports, data notes and more

- The peer review process is transparent and collaborative

- Your article is indexed in PubMed after passing peer review

- Dedicated customer support at every stage

For pre-submission enquiries, contact research@f1000.com 